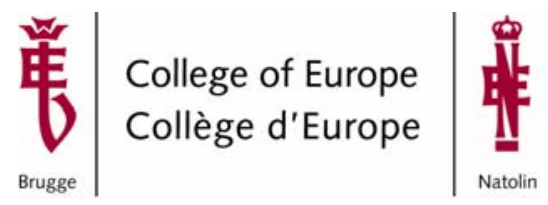

Bruges European Economic Research papers http://www.coleurope.eu/eco/publications.htm

\title{
The Determinants of Investment in Information and Communication Technologies
}

\author{
by Paolo Guerrieri, Matteo Luciani* \\ University of Rome "La Sapienza" \\ and Valentina Meliciani** \\ University of Teramo
}

\footnotetext{
* University of Rome "La Sapienza”, e-mail: paolo.guerrieri@uniroma1.it; matteo.luciani@uniroma1.it

*** University of Teramo, Viale Crucioli 122, e-mail: vmeliciani@unite.it
} 


\begin{abstract}
In this paper we investigate the determinants of ICT investment at the macro level for a panel of ten countries over the period 1992-2005. We argue that, since ICT is a General Purpose Technology, its diffusion can be understood only considering the interaction with institutional and structural factors. The empirical results are in line with this view: facilitating factors such as changes in regulation, human capital and the sectoral composition of the economy are relevant determinants for increasing ICT investment.
\end{abstract}

Keywords: Information and Communication Technologies, General Purpose Technologies, Structural change, Human capital, Regulation

JEL Codes: O33, O4, C33 


\title{
The Determinants of Investment in Information and Communication Technologies
}

\author{
Paolo Guerrieri, Matteo Lucani and Valentina Meliciani
}

BEER paper $n^{\circ} 16$

\section{1) Introduction}

Many studies have attempted to assess the contribution of ICT to growth performance and empirical works have flourished both at the macro and at the micro level, finding overall a positive impact of ICT on productivity and growth (for a review see Guerrieri and Padoan 2007).

In addition to the conclusion that ICT investment enhances productivity, the literature has shown that there are large differences across countries in the production, use and economic impact of ICT. International comparisons of the role of ICT in industrial countries have shown that two, or possibly three, groups of national patterns can be identified (Schreyer 2000). Within Europe, Daveri (2000) identifies laggards (Italy, Spain and to a lesser extent, Germany and France) and fast adopters (the UK, Netherlands, Sweden, Finland).

Why does the adoption of ICT differs so much also across industrialised countries? What are the factors that enhance or are detrimental to investing and benefiting from the investment in ICT?

In this paper we argue that, in order to address this question, it is necessary to recognise that ICT is a General Purpose Technology $(\mathrm{GPT})^{1}$ and that this implies that the coevolution of the technology, the structure of the economy, organizational and institutional factors is determinant for the overall success of the introduction of these technologies.

In the context of GPT, Lipsey, Carlaw and Bekar (2005) offer a Structuralist-Evolutionary (S-E) representation of the relationship between technology and the economy in which economic performance is determined by the interaction between inputs and the existing facilitating and policy structure. In the S-E approach natural endowments are the only exogenous inputs; the facilitating structure includes technology, infrastructure, physical capital, human capital, people, labour practices, and so on; while the policy structure is the set of realizations that provides the means of achieving public policies (public sector institutions, regulatory bodies, etc, including people that staff these organizations).

\footnotetext{
${ }^{1}$ GPTs are radical new ideas or techniques that have the potential for important impacts on many industries in an economy. Bresnahan and Trajtenberg (1995) identified three key characteristics of GPTs: commonness (they are used as inputs by many downstream industries); technological dynamism (inherent potential for technical improvements); and innovational complementarities with other forms of advancement (meaning that the productivity of R\&D in downstream industries increases as a consequence of innovation in the GPT).
} 
The complex interactions outlined by the GPT approach can help to explain why some countries have more problems in adopting a GPT as compared to others: the potential mismatches between technology, the facilitating structure and the policy structure may be weaker or stronger depending from country to country.

In order to analyze the impact of GPTs (hence of ICTs), it is thus necessary to take into account the interaction between the new technologies, institutions, the structure of the economy and other "facilitating factors". Some attempts in this direction include taking a sectorial perspective by distinguishing between ICT producing, ICT using and non-ICT industries (van Ark, Inklaar and McGuckin 2003) and explicitly modelling the interaction between ICT, producer services and the structure of the economy (Guerrieri et al. 2005).

This paper makes another step forward in this direction by analyzing the determinants of diffusion of Information and Communication Technologies (ICTs) within advanced countries, taking into account that ICTs are GPTs and, therefore, that their development is strongly linked to the "general business environment", including the role of institutions, the regulatory environment, human capital, the sectorial composition of the economy. Out of intrinsic interest, the study of the determinants of ICT investments has also relevant policy implications as increasing the ICT investment is one of the objectives set by the Lisbon Agenda. However, in order to reach this goal, it is necessary first to understand what the factors that encourage/discourage ICT investments are.

The analyses have been carried out with yearly observations from 1992 to 2005 on a panel of ten countries (Austria, Denmark, Finland, Germany, Italy, the Netherlands, Sweden, the United Kingdom, the United States, and Japan). The empirical results are in line with the literature: facilitating factors are relevant determinants for the spread of general purpose technologies such as ICT to the extent that they influence the business environment. Human capital is a factor that increases ICT investments, while burdensome regulation tends to depress them. Also, the structure of the economy turns out to be a relevant factor to understand the different rate of investment in ICT; in particular, countries with a higher share of the service sector (some categories of producer services) usually display higher ICT investment. Finally, although the intuition that in order to make R\&D profitable countries require updated IT equipments and software, no econometric robust conclusions can be driven on whether countries that invest more in R\&D are also those who invest more in ICTs.

The rest of the paper is organized as follows: Section 2 presents preliminary theoretical considerations on the determinants of ICT investment, Section 3 reviews the results obtained by the empirical literature on ICT adoption, while the empirical analysis is presented in section 4. Finally, section 5 concludes

\section{2) Preliminary considerations}

Considering ICT as a GPT means to recognise that firms do not simply use ICT capital in the production process as long as its marginal product is greater than or equal to its marginal cost, but that ICT investments respond to economic incentives that are different and more complex than those that characterize other kinds of investments. In this setting the returns to ICT investments are strongly affected by the general business environment where the investment takes place. 
The empirical literature gives support to the view that ICTs are not comparable to other capital goods. Many papers have pointed to ICT diffusion as the source of the resurgence of labour productivity after 1995 in the US (Jorgenson and Stiroh 2000, and Oliner and Sichel 2000). The outstanding performance of the US economy came from technological advancements in the ICT producing sector, from capital deepening due to ICT investment, and from total factor productivity gains in the ICT using sector essentially due to the use of ICTs.

As ICT is a General Purpose Technology it can be used by almost every sector, and most likely every firm that begins a process of investment in ICTs sooner or later will face a new set of possibilities in terms of, for example, organization of the production process, or business possibilities. Starting from this consideration, some authors (Basu and Fernald 2007 among others) argue that the performance of the US economy in the 2000s is still strongly influenced by ICT: however, while in the second half of the 90s the impact of ICT was "direct", in the 2000s the idea is that firms are implementing all those complementary investments necessary to make ICT capital more profitable and thus that ICT exerted an "indirect" effect. ${ }^{2}$

Therefore, in order to understand and model ICT diffusion it is necessary not to concentrate attention on the expected future return of the single investment, rather on the entire environment within and surrounding the firm that is able to influence the incentives and capability to undertake such investment. Not surprisingly, as we will see in the next paragraph, among the explanatory factors of ICT diffusion the literature has identified several variables related to the general business environment.

\section{3) Review of the literature}

In this section we will review the relevant empirical results on ICT adoption both at the macro and at the micro level.

The topic of ICT diffusion has received increasing attention. At the macro level, the literature has mostly concentrated on the digitial divide, i.e. the striking difference in the adoption of information technologies between developed and developing countries. At the micro level, instead, the literature focused on the identification of those characteristics (both specific to the firm and to the environment in which the firm operates) that are able to influence firms' decisions to invest in ICT.

In this paper we try to understand what are the factors that boost/depress ICT investments at the macro level. The analysis of the factors that drive ICT investment in advanced countries and the emphasis on ICTs as GPTs are a novelty of this study. However this topic is somewhat related to both the micro literature and the digital divide literature. In particular, this paper is closer to the micro literature because it studies ICT adoption from the point of view of the firm rather than of the consumer. Understanding what drives the single firm's behaviour is crucial in order to understand the results at the aggregate level.

\footnotetext{
${ }^{2}$ With complementary investment we mean organizational changes such as those that can be brought about by the automation of some production process, or the exploitation of new business possibilities such as for example those coming from $e$-commerce.
} 
At the same time, even though the digitial divide literature puts attention to diffusion of ICTs in a broader sense than investment, we believe that the results reached by these studies may be relevant also to identify the determinants of ICT investment.

Finally, it is important to point out that in the literature we review, the endogenous variable (i.e. ICT) has been measured by means of different variables: number of internet host per capita, computer per capita, internet connection per capita, internet users, mobile phones per capita, a dummy variable indicating if the firm uses computers, and other formulations. In what follows we do not make a distinction on the endogenous variable used, and we will generally call it ICT. This choice is intended to enhance the readability of this review; we refer the reader to table I for details about the papers cited here.

There is a widespread agreement that the digital divide is mostly due to the difference in economic wealth of countries. Caselli and Coleman (2001), Baliamoune-Lutz (2003), Pohjola (2003), Chinn and Fairlie (2007), and Wunnava and Leiter (2009), by analyzing a sample including both developing and developed countries, provide empirical evidence that income per capita is positively and significantly related to ICT adoption, while Dasgupta, Lall and Wheeler (2001) find that the relationship is not significant. Beilock and Dimitrova (2003) show that the relationship between income and ICT diffusion is not linear and that income matters more for poor countries. Finally, Hargittai (1999) by estimating a model on a sample of OECD countries argues that income per capita per se is not sufficient to explain the digitial divide, and suggests that income distribution needs to be considered as well.

Another factor that is widely considered in the literature, both at the macro and at the micro level is Human Capital. From a theoretical point of view, the argument is that skilled (i.e. educated) workers are more capable of learning how to use new technologies and that they are more flexible with respect to their job assignment. Because the adoption of ICT often requires a reorganization of the firm, a firm with a high percentage of skilled workers can implement more easily information technologies. In the macro literature, those authors who analyze samples including both developed and developing countries find mixed evidence (Baliamoune-Lutz, 2003, Crenshaw and Robinson, 2006, Chinn and Fairlie, 2007, and Wunnava and Leiter, 2008), whereas those who analyze OECD countries find a significant influence of the level of human capital on ICT adoption (Hargittai 1999; Gust and Marquez 2004). ${ }^{3}$ Studies at the micro level, instead, find a positive relationship between the general level of employee qualification and ICT use (Bayo-Moriones and Lera-Lopez 2007; Haller and Traistaru-Siedschlag 2007).

The impact of regulation on the adoption of ICT has received much attention in the literature. In general, it has been argued that all kinds of restrictions, regulations or constraints that somehow limit the set of decisions of an economic agent, may drive the economy to a sub-optimal equilibrium. The question is if they also negatively influence the adoption of ICT. Gust and Marquez (2004) demonstrate that regulation in the labour market slows down the process of adoption, Dasgupta, Lall and Wheeler (2001) that competition policy matters, while Hargittai (1999) focuses on the influences of the structure of the telecom market (monopoly $v s$. competition).

\footnotetext{
${ }^{3}$ By starting from the consideration that the language of most web sites is English, some of these authors have also tested that, in addition to an education variable, English proficiency is a further explanatory variable for ICT adoption. However, other empirical results do not support this hypothesis (Hargittai 1999; Caselli and Coleman 2001).
} 
TABLE I - Review of the Literature Summary Table.

\begin{tabular}{|c|c|c|c|}
\hline Authors & Dependent Variable & $\begin{array}{l}\text { Time } \\
\text { Coverage }\end{array}$ & $\begin{array}{c}N^{\circ} \text { of } \\
\text { Countries }\end{array}$ \\
\hline Baliamoune-Lutz (2003) & Internet users - Mobile Subscribers - PC - Internet host & 1998-2000 & 47 \\
\hline Beilock and Dimitrova (2003) & Internet users & $\mathrm{CC}^{\S}$ & 105 \\
\hline Caselli and Coleman II (2001) & Computer imports per worker - OCAM & $1970-1990$ & 155 \\
\hline Chinn and Fairlie (2004) & Internet users $-\mathrm{PC}^{*}$ & $1990-2001$ & 161 \\
\hline Crenshaw and Robison (2006) & Internet Hosts & $1995-2000$ & 50 \\
\hline Dasgupta, Lall, and Wheeler (2001) & Internet Subscribers - Telephone Mainline & 1990-1997 & 44 \\
\hline Gust and Marquez (2004) & IT production ( $\%$ of GDP) - Expenditure on IT ( $\%$ of GDP) & $1991-1998$ & 13 \\
\hline Hargittai (1999) & Internet Hosts & 1998 & 18 \\
\hline Luciani and Padoan (2007) & $\begin{array}{l}\text { IT Expenditure (\% of GDP) - IT and Software Capital } \\
\text { Formation }\end{array}$ & $1980-2004$ & 11 \\
\hline Pohjola (2003) & $\begin{array}{l}\text { Computer Hardware per capita - Expenditure on IT ( } \% \text { of } \\
\text { GDP) }\end{array}$ & $1993-2001$ & 51 \\
\hline Wunnava and Leiter (2008) & Internet users & $\mathrm{CC}^{\S}$ & 100 \\
\hline Bayo-Moriones and Lera-Lopez (2007) & $\begin{array}{l}\text { PCs per employee, Computer Users, Videoconference, } \\
\text { intranet and extranet, website, e-mail users, internet access } \\
\text { point per employee, e-mail accounts per employee }\end{array}$ & 2002 & $\begin{array}{l}\text { Spain } \\
337 \text { firms }\end{array}$ \\
\hline Haller and Traistaru-Siedschlag (2007) & $\begin{array}{l}\text { Computers use } \mathrm{d}^{\text {, }} \text {, orders via the Internet, services offered } \\
\text { online, share of employees using a computer, share of sales } \\
\text { (turnover) due to transactions over the Internet }\end{array}$ & $2002-2004$ & $\begin{array}{l}\text { Ireland } \\
4879 \text { firms }\end{array}$ \\
\hline Hollenstein (2004) & $\begin{array}{l}\text { adoption of Internet, the adoption of Internet-based selling, } \\
\text { overall ICT intensity (ICTINT), proportion of employees } \\
\text { regularly working with internet }\end{array}$ & 2000 & $\begin{array}{l}\text { Switzerland } \\
2641 \text { firms }\end{array}$ \\
\hline
\end{tabular}


Some authors analyzing the digital divide have also included indices of property rights and/or of civil liberties that resulted to be important variables as well (Caselli and Coleman 2001; Baliamoune-Lutz 2003; Crenshew and Robinson 2006; Chinn and Fairlie 2007; Wunnava and Leiter 2009).

Demographic factors such as the age structure of the population and the size of urban population have also been taken into account. The idea is that ICT have larger diffusion among younger people and that urban population tends to adopt more ICT (internet and computer) because of network economies. However, the empirical evidence is mixed. Regarding population age: Chinn and Fairlie (2007) argue that if the developing countries had the same population age composition of the US, the divergence in adoption of ICT would have been even larger; on the other hand Bayo-Moriones and Lera-Lopez (2007) find no relationship between workforce age and ICT at the firm level. With respect to urban population: Dasgupta, Lall and Wheeler (2001) and Crenshew and Robinson (2006) find a positive elasticity with ICT adoption while Chinn and Fairlie (2007) find it negative. Chinn and Fairlie (2007) explain this result through the inclusion of a telephone line density variable: "this finding suggests that after controlling for telephone line density in a country, the Internet substitutes for the benefits accruing to operating in an urbanized environment" (p. 14).

Knowledge spillovers, network externalities, and competitive pressure are all factors that could play a relevant role in firms' (and thus countries') adoption of ICTs. Hollenstein (2004) argues that for firms being able to understand future benefits and costs of ICT investments is fundamental: therefore the possibility to absorb knowledge from other firms is a factor that influences firms' adoption of ICTs. Haller and Traistaru-Siedschlag (2007) find that in Ireland firms located in the capital city region are those who adopt more ICTs, and Bayo-Moriones and Lera-Lopez (2007) find that competitive pressure encourages the adoption of ICT. At the macro level technological spillovers can derive for example from relationships with foreign (perhaps more advanced) countries. That is why many authors investigated the relationship between the degree of openness of an economy and ICT adoption. However, empirical evidence does not allow for a clean conclusion: Caselli and Coleman (2001) and Baliamoune-Lutz (2003) find a positive relationship, while Pohjola (2003) and Chinn and Fairlie (2007) find it to be not significant. Caselli and Coleman (2001) also investigate if the source of imports matters and find that imports from OECD countries are significant while imports from non-OECD are not.

The economic structure of a country has shown to be relevant for ICT adoption. The empirical analysis mainly tried to answer two questions, namely: i) what are the Firm's specific characteristics that influence the adoption of ICTs? and ii) Does sectorial composition of a country play a role in terms of ICT performances? Many authors find that firm's size is a relevant variable for ICT investment decisions (Haller and TraistaruSiedschlag 2007): given that larger firms face less financial constraints, the larger the firm, the higher the probability of adopting new technologies. Moreover, Hollenstein (2004) clarify that firm size matters only for firms with more than 200 employees, and that the explanatory variables of the model play a different role for small firms and for large firms, in particular with small firms that look for a quick return on investments In addition to firms' size, organizational structure has shown to be a relevant as well: Hollenstein (2004) suggests that team working and horizontal structure are organizational characteristics that encourage ICT adoption. 
The answer to the second question is positive as well: given that some sectors use more ICT than others, different sectorial composition determines different rates of investment in ICT. The literature emphasizes how the higher the share of the service, and of the manufacturing sector, the higher the ICT investment rate, while an inverse relation exists with agriculture and public sector (Caselli and Coleman 2001; Gust and Marquez 2004). Where the rationale for this last result is that the public sector often lacks the incentive to obtain high productivity standard, thus to innovate, and so to adopt ICT.

Finally, there is not yet agreement on the use of a price index as a determinant of ICT use. The straightforward idea is that if price fall the quantity demanded increases. Pohjola (2003) includes a price index in his regression and finds it to be significant, while Chinn and Fairlie (2007) argue that given that prices exhibit a downward trend they should not be included in the analysis.

\section{4) The empirical analysis}

\subsection{Variables and data}

As we have seen in the review of the literature there are many factors that may influence ICT investment/expenditure/adoption, and not surprisingly many of them relate to the set of "facilitating factors", i.e. variables influencing the general business environment. We have therefore concentrated our analysis on some of these "facilitating factors", namely: 1) the economic structure (the sectorial composition of the economy);2) human capital; 3) complementary expenditure on technology; 4) the regulatory environment. ${ }^{4}$ Differently, although the macro literature on ICT adoption has put lots of emphasis on economic wealth as a determinant of ICTs diffusion we will not consider it. In fact, while the availability of resources may constraint the possibility of undertaking such investment in less developed countries, we believe that for advanced countries this constraint would not bind. In order to explain why these countries invest different share of their GDP we rather believe it is necessary to look at those variables that relate to the set of "facilitating factors".

To proxy the sectorial composition of the economy we have considered the share of some categories of producer services on the economy (services). These are: Post and Telecommunications, Finance, Insurance, Real Estate and Business Services. We have chosen these services since in previous studies it has been shown that their production and trade is strongly linked to investments in ICT (for a review of the relationship between these services and ICT see Guerrieri and Meliciani 2005). Given that these services are heavy users of information technologies, we expect that, ceteris paribus, countries with a higher share of these activities have a higher rate of investment in ICTs.

To proxy human capital, in accordance with the literature, we included several measures. The first measure we consider is the share of researchers in total employment (henceforth researchers). This variable captures a very "sophisticated" kind of human capital. Moreover, as it was to be expected, it is strongly correlated with the expenditures on R\&D (the correlation coefficient is 0.93 ). Therefore we consider also other proxies for measuring human capital.

\footnotetext{
${ }^{4}$ For a precise definition of the variables see the appendix.
} 
First, we took data from Eurostat on Spending on Human Resources (shr). However, it is necessary to point out that shr is not a variable commonly used in empirical analyses as the empirical literature always measures Human Capital from an "education-based" point of view, rather than a "cost-based" point of view (Le, Gibson and Oxley 2005). Secondly we used the share of population having completed at least upper secondary education. The limit of this variable is that it is available only for European countries and only starting from 1998 and that it has a low variability across countries for the sample of advanced countries included in this study. The introduction of different indicators of human capital should also help assessing whether for stimulating ICT investment it is more important to achieve a satisfactory level of general education or to focus on more specific highly educated human resources.

In order to capture complementary expenditure in technology, we have included the ratio of Gross Expenditures on Research and Development (GERD) on GDP. This is consistent with the GPT literature that stresses the importance of innovation complementarities: on the one hand in order to make R\&D profitable countries require updated IT equipments and software and on the other high R\&D efforts favour the development and diffusion of new technologies such as ICTs.

In order to take into account for the impact of the regulatory environment on firms' ICT expenditure, we introduce some variables that capture the national degree of regulation. In particular, the level of regulation is measured by three different indices: an index of Regulatory Conditions in Seven Non-Manufacturing Sectors (Regulation) constructed by Conway and Nicoletti (2006), an Index of Administrative Burdens on Start-ups (absu) taken from Conway, Janod and Nicoletti (2005), and an index of Employment Protection Legislation (epl) taken from the OECD Employment Outlook 2004. ${ }^{5}$ Although the three indices all measure the tightness of regulation, they focus on different aspects: respectively restrictions to competition, administrative burdens and flexibility of the labour market. We think that assessing whether these different forms of regulation have different impacts on incentives to adopt new technologies has important policy implications since it allows to discriminate what kind of deregulation (if any) works better in stimulating ICT.

Finally, the endogenous variable is the ratio of ICT investment to GDP (henceforth ICT). ICT investments are computed as the sum of Gross fixed capital formation of IT equipment, Communication equipment, and Software.

The analysis is carried out on a panel of ten countries (Austria, Denmark, Finland, Germany, Italy, the Netherlands, Sweden, the United Kingdom, the United States, and Japan) with yearly observations from 1992 to 2005. The sample is unbalanced since we decided not to fill in missing values by interpolation or any other methodology (table II). Table II reports mean values for the variables used in the regression over the whole period of analysis for the sample of countries considered in the empirical analysis. ${ }^{6}$

\footnotetext{
${ }^{5}$ The index regulation has both a time series and a cross sectional dimension, whereas absu and epl are characterized mainly by a cross sectional dimension. This is because regulation has been computed every year, while $a b s u$ and $e p l$ have not. In particular, $a b s u$ has been computed only for 1998 and for 2003. Regarding epl, with some exceptions, it has been computed for 1990, 1998, and 2003.

${ }^{6}$ The choice of reporting mean values only is mainly due to graphical reason. Complete descriptive statistics are available upon request.
} 
TABLE II - Mean Values. ${ }^{1}$

\begin{tabular}{|c|c|c|c|c|c|c|c|c|c|c|c|c|c|c|c|c|c|c|c|c|c|c|c|c|c|c|c|}
\hline & \multicolumn{3}{|c|}{ ict } & \multicolumn{3}{|c|}{ gerd } & \multicolumn{3}{|c|}{ services } & \multicolumn{3}{|c|}{ regulation } & \multicolumn{3}{|c|}{$a b s u$} & \multicolumn{3}{|c|}{ epl } & \multicolumn{3}{|c|}{ hc } & \multicolumn{3}{|c|}{$s h r$} & \multicolumn{3}{|c|}{ secondary ${ }^{2}$} \\
\hline & $a$ & $b$ & $c$ & $a$ & $b$ & $c$ & $a$ & $b$ & $c$ & $a$ & $b$ & $c$ & $a$ & $b$ & $c$ & $a$ & $b$ & $c$ & $a$ & $b$ & $c$ & $a$ & $b$ & $c$ & $a$ & $b$ & $c$ \\
\hline AUT & 2.0 & 2.1 & 2.4 & 1.5 & 1.7 & 2.1 & 21.0 & 23.1 & 24.6 & 4.3 & 3.8 & 2.6 & 2.6 & 2.6 & 2.7 & 2.2 & 2.2 & 2.1 & 0.3 & 0.5 & 0.6 & - & 5.9 & 5.6 & - & 72.3 & 78.6 \\
\hline DNK & 3.2 & 3.5 & 3.8 & 1.7 & 2.0 & 2.5 & 24.5 & 24.2 & 25.5 & 4.4 & 3.1 & 1.9 & 0.5 & 0.5 & 0.5 & 2.3 & 1.4 & 1.4 & 0.5 & 0.6 & 0.9 & - & 8.0 & 8.4 & 77.3 & 78.8 & 80.1 \\
\hline FIN & 2.5 & 2.9 & 3.0 & 2.1 & 2.7 & 3.4 & 20.7 & 21.8 & 23.9 & 4.1 & 2.8 & 2.4 & 2.0 & 2.0 & 1.7 & 2.2 & 2.1 & 2.0 & 0.7 & 1.2 & 1.6 & 7.0 & 6.6 & 6.2 & - & 69.2 & 75.7 \\
\hline GER & 2.4 & 2.3 & 2.3 & 2.3 & 2.3 & 2.5 & 27.2 & 29.4 & 30.8 & 4.3 & 3.1 & 1.9 & 2.4 & 2.4 & 2.0 & 3.2 & 2.7 & 2.3 & 0.6 & 0.6 & 0.7 & - & 4.6 & 4.6 & 80.4 & 80.0 & 82.8 \\
\hline ITA & 2.0 & 2.2 & 2.2 & 1.1 & 1.0 & 1.1 & 23.1 & 24.8 & 28.1 & 5.5 & 4.7 & 3.0 & 4.6 & 4.6 & 3.5 & 3.6 & 3.2 & 2.1 & 0.3 & 0.3 & 0.3 & 5.3 & 4.7 & 4.6 & 33.7 & 39.7 & 46.4 \\
\hline JPN & 2.7 & 3.2 & 3.1 & 2.9 & 2.9 & 3.1 & 22.8 & 24.9 & 27.4 & 3.3 & 3.0 & 2.4 & 2.1 & 2.1 & 2.0 & 2.1 & 2.0 & 1.8 & 1.0 & 1.0 & 1.0 & 3.5 & 3.6 & 3.7 & - & - & - \\
\hline NLD & 2.7 & 3.1 & 3.2 & 1.9 & 1.9 & 1.8 & 24.4 & 28.0 & 29.7 & 4.5 & 3.1 & 1.8 & 1.8 & 1.8 & 1.7 & 2.7 & 2.6 & 2.1 & 0.5 & 0.5 & 0.5 & 5.2 & 4.9 & 5.0 & - & 64.2 & 68.8 \\
\hline SWE & 3.2 & 3.9 & 4.0 & 2.9 & 3.5 & 4.1 & 25.2 & 26.4 & 27.5 & 3.5 & 2.5 & 2.0 & 1.1 & 1.1 & 1.2 & 3.0 & 2.3 & 2.2 & 0.7 & 0.9 & 1.1 & 7.3 & 7.5 & 7.2 & - & 75.0 & 81.3 \\
\hline UK & 2.9 & 4.0 & 4.1 & 2.0 & 1.9 & 1.9 & 25.1 & 27.1 & 31.0 & 2.4 & 1.5 & 1.1 & 1.0 & 1.0 & 0.8 & 0.6 & 0.6 & 0.7 & 0.5 & 0.5 & - & 5.3 & 4.9 & 5.1 & 50.3 & 55.7 & 67.8 \\
\hline US & 2.9 & 3.8 & 3.9 & 2.6 & 2.6 & 2.7 & 29.3 & 30.7 & 31.5 & 2.2 & 1.7 & 1.5 & 0.9 & 0.9 & 1.0 & 0.2 & 0.2 & 0.2 & 0.8 & 0.9 & 0.9 & 4.9 & 4.9 & 5.1 & 79.7 & 82.3 & 84.6 \\
\hline
\end{tabular}


From the table we can observe that:

1. as far as ICT is concerned it is possible to identify three groups of countries: the UK, the US, Sweden and Denmark are the countries that invested the most and that have reached values of about $4 \%$ at the end of the period; Finland, Japan, and the Netherlands exhibit a slow increasing pattern during the nineties, and overall show values around 3\%; Austria, Germany and Italy are the countries that performed poorly with values below $2.5 \%$;

2. the share of services has increased in all countries during the sample period, with the US and the UK showing on average the highest values;

3. the GERD/GDP ratio has remained stable in most countries while it has increased in Austria, Denmark, Finland, and Sweden (Finland and Sweden also show the highest values together with Japan);

4. about human capital indicators:

4.1. $h c$ and $s h r$ do not exhibit noteworthy pattern;

4.2. the share of population having completed at least upper secondary education is on average similar between countries with the notable exception of Italy that shows the lowest values;

5. about regulation indices:

5.1. the regulation index has decreased almost everywhere and, at the same time its dispersion across countries has also decreased;

5.2. as far as administrative burdens on start ups are concerned the less regulated countries are the UK, the US and the North European countries;

5.3. the epl index has decreased substantially in all European countries but the UK. This is due to labour market reforms that have been implemented during the ' $80 \mathrm{~s}$ and ' $90 \mathrm{~s}$ in order to increase the flexibility of labour market. In particular, this reforms have substantially diminished the constraint and limit in the use of temporary work;

these different patterns across countries of regulation of the labor market compared to the presence of administrative burdens and degree of competition is an interesting feature that should be kept in mind when looking at regression results.

\subsection{Estimation results}

Table III shows estimates of an Instrumental Variables Random Effects model for ICT investment. The IV estimation is motivated by the potential endogeneity of services with respect to ICT. This potential endogeneity comes from the background framework that we have in mind that is the model of Guerrieri, et al. (2005). In this model services, i.e. the amount of intermediate inputs available for the production of the final good, increases with ICT, therefore services is endogenous with respect to ICT.

Panel $a$, and $b$ of table III present estimates with different human capital measures: respectively researchers, and $s h r$, whereas the three columns within each panel present different specifications with respect to the regulation variables: the first including the regulation index, the second including the absu index, and the third including the epl index. 
In all regressions we have also included three time dummies to capture the economy slowdown that followed the $9 / 11$.

In all estimations we found a positive relation between ICT and services with the elasticity of the ICT/GDP to services varying between 0.48 and 1.34 .

The results for human capital are mixed: we found a positive and significant relation between human capital and ICT when human capital is measured with researchers while when it is measured with shr the coefficient is not significant. This result is not surprising. Indeed, as we have already pointed out, shr is a "cost-based" indicator of human capital, and usually "education based" indicators are supposed to be more appropriate for macroeconometric analyses. We thought, however, it was worth considering this variable as it can be considered as an indicator of "general" human capital. In fact, one interesting issue to address is whether, in terms of ICT diffusion, it matters more scientific human capital or general human capital. That is a relevant question in terms of EU policy as two of the objectives of the Lisbon agenda are of increasing the number of graduates in mathematics, science, technology and engineering, and of reaching a rate of $80 \%$ of the working age population with at least a completed upper secondary degree.

TABLE III - Generalized 2SLS Random Effect IV Estimates for ICT Equation.

\begin{tabular}{|c|c|c|c|c|c|c|}
\hline & $1 a$ & $2 a$ & $3 a$ & $1 b$ & $2 b$ & $3 b$ \\
\hline \multirow[t]{2}{*}{ services } & $0.848^{* * *}$ & $1.131^{* * *}$ & $1.2^{* * *}$ & $0.757^{* *}$ & $0.487^{* *}$ & $1.344^{* * *}$ \\
\hline & 0.28 & 0.231 & 0.269 & 0.318 & 0.197 & 0.271 \\
\hline \multirow[t]{2}{*}{$G E R D$} & -0.033 & -0.101 & -0.10 & $0.213^{* *}$ & $0.139^{* *}$ & 0.153 \\
\hline & 0.154 & 0.173 & 0.186 & 0.084 & 0.056 & 0.104 \\
\hline \multirow[t]{2}{*}{ human capital } & $0.214^{* *}$ & $0.295^{* *}$ & $0.31^{* *}$ & 0.185 & -0.06 & -0.024 \\
\hline & 0.108 & 0.122 & 0.127 & 0.15 & 0.106 & 0.197 \\
\hline \multirow[t]{2}{*}{ regulation } & $-0.324^{* * *}$ & & & $-0.394^{* * *}$ & & \\
\hline & 0.065 & & & 0.073 & & \\
\hline \multirow[t]{2}{*}{$a b s u$} & & $-0.118^{* *}$ & & & $-0.238^{* * *}$ & \\
\hline & & 0.056 & & & 0.041 & \\
\hline \multirow[t]{2}{*}{ labour } & & & -0.072 & & & 0.032 \\
\hline & & & 0.059 & & & 0.0733 \\
\hline \multirow[t]{2}{*}{$d \_2001$} & $-0.078^{* * *}$ & 0.017 & 0.004 & $-0.07^{* *}$ & $0.089^{*}$ & 0.04 \\
\hline & 0.033 & 0.041 & 0.039 & 0.033 & 0.047 & 0.039 \\
\hline \multirow[t]{2}{*}{ d_2002 } & $-0.193^{* * *}$ & $-0.075^{*}$ & $-0.09^{* *}$ & $-0.194^{* * *}$ & 0.001 & -0.057 \\
\hline & 0.036 & 0.042 & 0.04 & 0.037 & 0.05 & 0.043 \\
\hline \multirow[t]{2}{*}{$d \_2003$} & $-0.273^{* *}$ & $-0.162^{* * *}$ & $-0.155^{* * *}$ & $-0.267^{* * *}$ & $-0.09^{* *}$ & $-0.114^{* * *}$ \\
\hline & 0.038 & 0.045 & 0.043 & 0.037 & 0.048 & 0.042 \\
\hline \multirow[t]{2}{*}{ constant } & -1.209 & $-2.34^{* * *}$ & $-2.567^{* * *}$ & -1.442 & -0.402 & $-3.392^{* * *}$ \\
\hline & 0.951 & 0.759 & 0.903 & 1.198 & 0.775 & 1.049 \\
\hline \multirow{3}{*}{$\begin{array}{c}\text { within } \\
\text { between } \\
\text { overall }\end{array}$} & 0.656 & 0.34 & 0.451 & 0.64 & 0.207 & 0.375 \\
\hline & 0.532 & 0.656 & 0.454 & 0.635 & 0.77 & 0.102 \\
\hline & 0.521 & 0.564 & 0.402 & 0.685 & 0.637 & 0.215 \\
\hline \multirow{2}{*}{$\begin{array}{c}\sigma_{\eta}^{2} / \sigma_{y}^{2} \\
\text { observations }\end{array}$} & 0.816 & 0.523 & 0.74 & 0.75 & 0.066 & 0.795 \\
\hline & 85 & 88 & 88 & 101 & 109 & 109 \\
\hline
\end{tabular}

All variables are log transformed. For each variable top line is point estimate, and bottom line is standard error. The variable services has been Instrumented with all other variables in the regression plus services $t_{\text {- }}$ 1. In panel $a$ the variable human capital is researcher, while in panel $b$ is $s h r$.

${ }^{*}$ Significant at $10 \% ;{ }^{* *}$ Significant at $5 \% ;{ }^{* * *}$ Significant at $1 \%$ 
To measure general human capital we also considered the percentage of working age population with at least an upper secondary degree (education). Unfortunately, data on education are available from Eurostat for European countries only and starting from 1998. This limitation in the sample has created serious problems in estimation. We run regressions with this variable and we obtained mixed results (the variable is not significant in the model with random effects but it is positive and significant in the model with fixed effects). ${ }^{7}$ We believe that this is due to the limited variability of this variable in the sample, and, in particular, to the limited variability between countries (table II). In fact, in a recent work Luciani and Padoan (2007), by estimating a model for software investment on a sample of fifteen European countries, found a positive and significant coefficient for education. In our sample, all countries but Italy exhibit similar values of education, whereas the sample used by Luciani and Padoan (2007) includes also countries with low levels of human capital such as Portugal, Spain, and Greece. The presence of this set of countries increases the variability of education thus making significant the coefficient for this variable.

Somehow linked to the performance of the human capital indicators is the performance of $G E R D$. In fact, when the human capital is researchers the variable GERD is not significant (probably due to the high correlation between researchers and GERD); whereas when the human capital indicator is $s h r$ the variable enters the equation with a positive and significant sign.

Overall it appears that what matters more for ICT investment across advanced countries is not the general level of education (probably also because this is very similar across these countries) but having a high share of researchers. This result may also depend on the fact that, differently from many other studies reviewed in the previous paragraph, we are not looking at ICT adoption by households but at ICT investment by firms.

Finally, as it was to be expected, tighter regulations depress ICT investment. With the exception of epl that is never significant, the other two indices perform well, with regulation being able to capture better the within dynamics, and absu being able to explain better the between differences. ${ }^{8}$ The performance of both indices is not surprising. In fact, on the one hand the regulation index measures the level of regulation of seven nonManufacturing sectors. Since services are heavy users of ICTs, not surprisingly the tighter the regulation in these markets, the lower are the investments in ICTs. On the other hand, the literature on the effects of regulation on the economy has reached the conclusion that countries where (controlling for other factors) firms face more entry barriers perform poorly, both in terms of GDP growth and in terms of innovation and technological progress (R\&D expenditures)..$^{9}$ Accordingly with this conclusion, the coefficient on $a b s u$ is negative and significant. Finally, the fact that the degree of flexibility in the labour market does not affect ICT is in contrast with the results found in other studies (e.g. Gust and Marquez 2004). The different results may depend on the different time period analyzed. In fact Gust and Marquez (2004) investigate the determinants of ICT spending in the 90s, while we extend the sample over the 2000s. The behaviour of the epl index in some countries in the 2000 s is strongly dependent on the reforms aimed at facilitating the use of temporary contracts.

\footnotetext{
${ }^{7}$ Results of these regressions are not reported but are available upon request.

${ }^{8}$ This result cannot be interpreted from an economic point of view as it is probably due to the fact that the $a b s u$ index has almost only the cross-section dimension, whereas regulation has also the time series dimension.

${ }^{9}$ For a review of the literature on the economic effects of regulation see Schiantarelli (2005).
} 
We claim, and find this result supportive of our claim, that the possibility of using temporary contracts does not represent an incentive for firms in investing in ICTs. Summing up: our results suggest that not all kinds of "deregulation" exert the same impact on ICT investment and that deregulation policies aimed at increasing ICT investments should be devoted to foster competition in services and to reduce administrative burdens on start ups rather than to reduce employment protection.

In conclusion, our results give support to the view of ICT as a GPT and, in particular, to the importance of the economic structure, human capital, complementary technologies and the regulatory environment as important facilitating factors for ICT investment.

\subsection{Robustness analysis}

In this section we evaluate our results with respect to model specification by firstly evaluating the possibility of fixed rather than random country effects, and then by considering the possibilities that past values of ICT investment are indeed relevant determinants of today's ICT investments .

As a first step we evaluate the robustness of our estimation by presenting IV Fixed Effects Estimates (table IV, column 1). Due to poor time series dimension in epl and absu this estimation is provided only for the equation including the regulation variable. Moreover, given that the performance of $s h r$ is poor we present robustness analysis only for the model which has researcher as a proxy for human capital. Qualitatively (sign and significance of parameters) the results are similar to those obtained with Random Effect. Quantitatively only the parameter of the variable services is substantially different: FE estimation predicts a stronger relation between ICT and services. Finally, by means of an Hausman (1978) test, in the bottom line of table IV we test random vs. fixed effect in the model. The test clearly indicates that a random effect model is preferred.

As a further robustness check we also consider the possibility that past ICT investments may contain important information to forecast today's investment level. However, introducing the lagged value of the dependent variable has not negligible econometric implications as both the random effects and the fixed effects estimators are inconsistent. ${ }^{10}$ Therefore, to estimate our new equation we use the GMM estimator proposed by Arellano and Bond (1991). The estimation is carried out by using the same set of exogenous variables as in the previous section but for shr and the regulation variable. In fact, the Arellano Bond estimator is a first difference estimator and given that both absu and epl have a limited time series dimension we had to focus on regulation only.

Due to our non-treatment of missing values this estimation is done on a sample of eight countries (Denmark, Finland, Germany, Italy, the Netherlands, the UK, the US, and Japan) with yearly data from 1992 to 2003 .

\footnotetext{
${ }^{10}$ Let us write the model as $y_{i t}=\alpha y_{i t-1}+\beta x_{i t}+\eta_{i}+v_{i t}$, where $x_{i t}$ is a vector of exogenous variable, $\eta_{i}$ is the country specific effects, and $v_{i t}$ is a white noise error, then: (i) the random effect estimator is inconsistent because, the assumption that the country specific effect is uncorrelated with the right hand side variables is necessarily violated, in fact: $E\left(\eta_{i}, y_{i t-1}\right)=E\left[\eta_{i}\left(\delta y_{i t-1}+\beta X_{i t}+\eta_{i}+v_{i t}\right)\right] \neq 0$ because at least $E\left(\eta_{i}^{2}\right)$ is $\neq 0$; (ii) the Fixed effects estimator is inconsistent because after the within transformation is applied there still is a problem of correlation between the transformed dependent variable and the white noise error, in fact: $E\left(\tilde{y}_{i, t-1,1}, i t\right)=E\left\{\left[y_{i t-1}-T^{1}\left(y_{i 1}+\ldots+y_{i T}\right)\right]\left[v_{i t-1}-T^{1}\right.\right.$ $\left.\left.\left(v_{i 1}+\ldots+v_{i T}\right)\right]\right\} \neq 0$.
} 
Moreover, as we have explained in the previous section, in order to overcome a problem of possible endogeneity we have considered the variable services not as strictly exogenous but as pre-determined. Table IV, column 2 shows the results of GMM estimation.

Results are qualitatively in line with those obtained with IV random effect: services enter positively and significantly the equation albeit with a considerable lower magnitude, while the coefficients of both regulation and researchers are pretty stable. Even in this new estimation the parameter of GERD turns out not to be significant. ${ }^{11}$

\section{TABLE IV - Robustness Analysis}

\begin{tabular}{|c|c|c|c|c|}
\hline & \multicolumn{3}{|c|}{$\begin{array}{c}\text { Fixed-effects } \\
\text { within IV Estimates }\end{array}$} & $\begin{array}{c}\text { GMM Estimation } \\
\text { Arellano-Bond (1991) }\end{array}$ \\
\hline$I C T_{t-1}$ & & & & $\begin{array}{c}0.545^{* * *} \\
0.077\end{array}$ \\
\hline services & & $\begin{array}{l}1.033^{* * *} \\
0.312\end{array}$ & & $\begin{array}{c}0.255^{* *} \\
0.135\end{array}$ \\
\hline$G E R D$ & & $\begin{array}{l}-0.04 \\
0.175\end{array}$ & & $\begin{array}{l}0.085 \\
0.103\end{array}$ \\
\hline researcher & & $\begin{array}{c}0.217^{*} \\
0.116\end{array}$ & & $\begin{array}{c}0.203^{*} \\
0.113\end{array}$ \\
\hline regulation & & $\begin{array}{c}-0.304^{* * *} \\
0.069\end{array}$ & & $\begin{array}{c}-0.215^{* * *} \\
0.055\end{array}$ \\
\hline$d \_2001$ & & $\begin{array}{c}-0.082^{* *} \\
0.035\end{array}$ & & $\begin{array}{c}-0.111^{* * *} \\
0.017\end{array}$ \\
\hline d_2002 & & $\begin{array}{c}-0.198^{* * *} \\
0.037\end{array}$ & & $\begin{array}{c}-0.181^{* * *} \\
0.026\end{array}$ \\
\hline$d \_2003$ & & $\begin{array}{c}-0.279^{* * *} \\
0.04\end{array}$ & & $\begin{array}{c}-0.205^{* * *} \\
0.054\end{array}$ \\
\hline constant & & $\begin{array}{r}-1.825^{*} \\
1.065\end{array}$ & & $\begin{array}{l}-0.06 \\
0.555\end{array}$ \\
\hline observations & & 85 & & 64 \\
\hline Test & Model & Statistic & $p$-value & 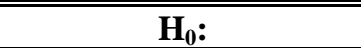 \\
\hline Hausman & $\mathrm{FE}$ & 1.91 & 0.965 & $\begin{array}{c}\text { difference in coefficients } \\
\text { not systematic } \\
\text { - i.e. random effect is } \\
\text { preferred - } \\
\text { no autocorrelation }\end{array}$ \\
\hline
\end{tabular}

All variables are log transformed. For each variable top line is point estimate, and bottom line is standard error. Robust standard error are shown for GMM estimation. IN the

For fixed effect regression, within $R^{2}$ is .65 , between $R^{2}$ is .5 , and overall $R^{2}$ is .49 ,

In fixed effect estimation, the variable services have been Instrumented with all other variables in the regression plus services ${ }_{t-1}$, while in GMM estimation the variable services is considered pre-determined.

${ }^{*}$ Significant at $10 \% ;{ }^{* *}$ Significant at $5 \% ;{ }^{* * *}$ Significant at $1 \%$.

11 We are perfectly aware that with just 64 observation, the reliability of the GMM estimator is seriously questioned. Despite this, we find the results obtained with GMM estimation encouraging because they are close to those obtained with IV random effects. 


\section{5) Conclusions}

In this paper we have investigated the determinants of ICT investment across European countries over the period 1992-2005. In line with the literature on GPT, and with the view that ICT is a GPT, we have found that a set of variables affecting the "general business environment" in which firms operate play a strategic role in firms' decision to invest in the new technologies. Among these variables the regulatory environment, human capital and the sectorial composition of the economy appear as important determinants of ICT investment. In particular, human capital and a high share of producer/business services in the economy are factors that increase ICT investment, while burdensome regulation tends to depress it.

Among human capital variables, we have found that a high share of researchers in total population is what matters most, while spending on human resources and having a high percentage of working age population with at least an upper secondary degree do not discriminate. This result may depend upon the sample of countries included in this paper that is composed of European countries with very similar levels of general education (with the exception of Italy) and on the fact that we are concentrating on expenditure by firms. In order to stimulate ICT investment across the most advanced European economies, efforts should be devoted to strengthening human capital at its highest levels more than to increasing the general level of education.

Among the regulation variables tight regulatory conditions in non-manufacturing sectors and high administrative burdens on start-ups have a negative impact on ICT investment, while employment protection legislation is not significant. This result qualifies the conclusions reached by other studies on the role played by "deregulation" in stimulating ICT investment by showing that not all kinds of deregulatory measures have the same impact, but concentrating on reducing administrative barriers and on liberalising service industries can be more effective than introducing higher degrees of flexibility in the labour market. 


\section{References:}

Arellano, M., and S. Bond. 1991. Some Tests of Specification for Panel Data: Monte Carlo Evidence and an Application to Employment Equations. Review of Economic Studies 58: 277-97.

Baliamoune-Lutz, M. 2003. An analysis of the Determinants and Effects of ICT Diffusion in Developing Countries. Information Technology for development 10: 151-169.

Basu, S., and J.G. Fernald. 2007. Information and communications technology as a general purpose technology: evidence from U.S. industry data. German Economic Review 8: 146-173.

Bayo-Moriones, J.A., and F. Lera-Lopez. 2007. A Firm Level Analysis of Determinants of ICT Adoption in Spain. Technovation 27: 352-366.

Beilock, R., and D.V. Dimitrova. 2003. An exploratory model of inter-country Internet diffusion. Telecommunications Policy 27:237-252.

Bresnahan, T.F., and M. Trajtenberg. 1995. General purpose technologies: Engines of growth. Journal of Econometrics 65: 83-108.

Caselli, F., and W.J. Coleman II. 2001. Cross-Country Technology Diffusion: The Case of Computers. American Economic Review 91: 328-335.

Chinn, M. D., and R. Fairlie. 2007. The Determinants of the Global Digital Divide: A Cross-Country Analysis of Computer and Internet Penetration. Oxford Economic Papers 59: 16 - 44.

Conway, P., V. Janod, and G. Nicoletti. 2005. Product Market Regulation in OECD Countries, 1998 to 2003. OECD Economics Department Working Paper n. 419.

Conway, P., and G. Nicoletti. 2006. Product market regulation in non-manufacturing sectors in OECD countries: measurement and highlights. OECD Economics Department Working Paper n. 530.

Crenshaw, E.M., and K.K. Robinson. 2006. Globalization and the Digital Divide: Roles of Structural Conduciveness and Global Connection in Internet Diffusion. Social Science Quarterly 87: 190-207.

Dasgupta, S., S. Lall, and D. Wheeler. 2001. Policy reform, economic growth, and the digital divide - an econometric analysis. World Bank Policy Research Working Paper Series n. 2567.

Daveri, F. 2000. Is growth in Europe an ICT story too?. IGIER Working Paper n. 168.

Guerrieri, P., B. Maggi, V. Meliciani, and P.C. Padoan. 2005. Technology diffusion, services and endogenous growth in Europe. Is the Lisbon strategy useful? Rivista di Politica Economica 95: 271-317.

Guerrieri, P., V. Meliciani. 2005. Technology and international competitiveness: The interdependence between manufacturing and producer services. Structural Change and Economic Dynamics 16: 489-502.

Guerrieri, P., and P.C. Padoan, eds. 2007. Modelling ICT as a General Purpose Technology, Collegium 35.

Gust, C., and J. Marquez. 2004. International comparisons of productivity growth: the role of information technology and regulatory practices, Labour Economics 11: 33-58.

Haller, S. and I. Traistaru-Siedschlag. 2007 The Adoption of ICT: Firm-Level Evidence from Irish Manufacturing Industries. Economic and Social Research Institute (ESRI) Working Paper n. 204. 
Hargittai, E. 1999. Explaining Differences in Internet Connectivity Among OECD Countries, Telecommunications Policy 23: 701-718.

Hausman, J.A. 1978. Specification Tests in Econometrics, Econometrica 46: 1251-1272.

Hollenstein, H. 2004. Determinants of the Adoption of Information and Communication Technologies, Structural Change and Economic Dynamics 15: 315-342.

Jorgenson, D.W., and K.J. Stiroh. 2000. Raising the Speed Limit: U.S. Economic Growth in the Information Age, Brookings Papers on Economic Activity 1: 125-211.

Le, T., J. Gibson, and L. Oxley. 2005. Measures of Human Capital: A Review of the Literature. New Zealand Treasury Working Paper 05/10.

Lipsey, R.G., K.I Carlaw, and C. Bekar. 2006. Economic Transformation. Oxford University Press.

Luciani, M., and P.C. Padoan. 2007. Endogenizing ICT: Quantitative Results. In Modelling ICT as a General Purpose Technology, ed. P. Guerrieri and P.C. Padoan, 147-171. Collegium 35.

Oliner, S. D., and D.E. Sichel. 2000. The Resurgence of Growth in the Late 1990s: Is Information Technology the Story? Journal of Economic Perspectives 14: 3-22.

Pohjola, M. 2003. The adoption and diffusion of ICT across countries: Patterns and determinants. In New Economy Handbook, ed. D.C. Jones. San Diego: Elsevier-Academic Press.

Schiantarelli, F. 2005. Product Market Regulation and Macroeconomic Performance: A Review of Cross Country Evidence", Boston College Working Paper 624.

Schreyer, P. 2000. The contribution of information and communication technology to output growth: a study of the G7 countries. OECD Science, Technology and Industry Working Papers n. 2000/2.

van Ark, B., R. Inklaar, and R.H. McGuckin. 2003. Changing Gear Productivity, ICT and Service Industries: Europe and the United States. In The industrial dynamics of the new digital economy, ed. J.F. Christensen and P. Maskell. Cheltenham: Edward Elgar.

White, H. 1980. A Heteroscedasticity-Consistent Covariance Matrix Estimator and a Direct Test for Heteroscedasticity, Econometrica 48: 817-838.

Wunnava, P.V., and D.B. Leiter. 2009. Determinants of Inter-Country Internet Diffusion Rates. The American Journal of Economics and Sociology 68: 413-426. 


\section{APPENDIX: data definitions and sources}

$I C T=$ Nominal gross fixed capital formation of Computing equipment + Communications equipment + Software divided by Gross value added at current basic prices. Source: EUKLEMS Database

services $=$ Ratio of the Gross value added at current basic prices Post and Telecommunications, Finance, Insurance, Real Estate, and Business Services Gross value added at current basic prices in all industries (01-99). Source: EUKLEMS Database

$G E R D=$ Gross Domestic Expenditure on R\&D (national currency) over Gross Domestic Product at Market Prices (national currency). Sources: MSTI database, OECD.

researchers $=$ Ratio of Total Researchers (Full Time Equivalent) to total Employment. Sources: MSTI Database, OECD.

$s h r=$ Spending on Human Resources Total public expenditure on education as a percentage of GDP. Source: Eurostat.

education $=$ Total population having completed at least upper secondary education, Population aged 25 to $64(\%)$. Source: Eurostat.

$a b s u=$ Index of Administrative Burdens on Start-ups. Sources: Conway, Janod and Nicoletti (2005). The absu index measures the administrative burdens on the creation of Corporations and the administrative burdens on the creation of sole proprietor firms.

regulation $=$ Index of Regulatory Conditions in Seven Non-Manufacturing Sectors: airlines, telecoms, electricity, gas, post, rail, and road freight. Source: Conway and Nicoletti (2006). The regulation index attempts to capture restrictions to competition in seven industries (Airlines, telecoms, electricity, gas, post, rail, and road freight); it is computed as an average of five "low-level" indicators: 1) barriers to entry, 2) public ownership, 3) vertical integration, 4) market structure, and 5) price controls.

$e p l=$ Overall Employment Protection Legislation. Source: OECD Employment Outlook 2004. The epl indicator, instead, tries to capture the strictness of employment protection legislation. It is the result of the aggregation of many indices that can be grouped in two broad areas: permanent contracts and temporary contracts. For permanent contracts three fields of regulation are considered: 1) the procedural requirements from the decision to lay off to the actual termination of the contract, 2) the notice and trial period, and 3) the direct cost of dismissal. The legislation of temporary contracts is described by means of the definition of types of labour and procedures, the maximum number of successive renewals, and the maximum cumulated duration of the contract. 


\section{List of ‘Bruges European Economic Research Papers’ (BEER)}

BEER paper $n^{\circ} 16$ (March 2010)

The Determinants of Investment in Information and Communication Technologies by Paolo Guerrieri, Matteo Luciani and Valentina Meliciani

BEER paper $n^{\circ} 15$ (December 2009)

Informational Barriers to Energy Efficiency - Theory and European Policies by Lars-Morten Andersen and Raimund Bleischwitz

BEER paper $n^{\circ} 14$ (December 2008)

EU Policies and Cluster Development of Hydrogen Communities by Raimund Bleischwitz, Nikolas Bader, Anne Nygaard Madsen and Per Dannemand Andersen

BEER paper $n^{\circ} 13$ (April 2008)

Economic Approaches of the Internal Market, by Jacques Pelkmans.

BEER paper $n^{\circ} 12$ (March 2008)

Cartels: the Probability of Getting Caught in the European Union, by Emmanuel Combe, Constance Monnier and Renaud Legal.

BEER paper $n^{\circ} 11$ (June 2007)

Regional Business Cycle Synchronization in Europe?, by Lourdes Acedo Montoya and Jakob de Haan.

BEER paper $n^{\circ} 10$ (March 2007)

Family Types and the Persistence of Regional Disparities in Europe, by Gilles Duranton, Andrés Rodríguez-Pose and Richard Sandall.

BEER paper $n^{\circ} 9$ (February 2007)

Analysing the Contribution of Business Services to European Economic Growth, by Henk Kox and Luis Rubalcaba.

BEER paper $n^{\circ} 8$ (November 2006)

The Determinants of Country Risk in Eastern European Countries. Evidence from Sovereign Bond Spreads, by Kiril Strahilov.

BEER paper $n^{\circ} 7$ (November 2006)

Regional business cycles and the emergence of sheltered economies in the southern periphery of Europe by Andrés Rodríguez-Pose and Ugo Fratesi.

BEER paper $n^{\circ} 6$ (November 2006)

The 2005 Reform of the Stability and Growth Pact: Too Little, Too Late?, by Fiorella Kostoris Padoa Schioppa.

BEER paper $n^{\circ} 5$ (October 2006)

R\&D, Spillovers, Innovation Systems and the Genesis of Regional Growth in Europe, by Andrés Rodríguez-Pose and Riccardo Crescenzi.

BEER paper $n^{\circ} 4$ (July 2006)

Mixed Public-Private Enterprises in Europe: Economic Theory and an Empirical Analysis of Italian Water Utilities, by Alessandro Marra.

BEER paper $n^{\circ} 3$ (November 2005)

Regional Wage And Employment Responses To Market Potential In The EU, by Keith Head \& Thierry Mayer. 
BEER paper $n^{\circ} 2$ (May 2005)

Technology diffusion, services and endogenous growth in Europe. Is the Lisbon Strategy still alive?, by Paolo Guerrieri , Bernardo Maggi, Valentina Meliciani \& Pier Carlo Padoan.

BEER paper $\mathrm{n}^{\circ} 1$ (November 2004)

Education, Migration, And Job Satisfaction: The Regional Returns Of Human Capital In The EU, by Andrés Rodríguez-Pose \& Montserrat Vilalta-Bufí.

\section{List of 'Bruges European Economic Policy briefings' (BEEP)}

BEEP briefing $n^{\circ} 19$ (September 2008)

The Policy Framework for the Promotion of Hydrogen and Fuel Cells in Europe, A Critical

Assessment, by Raimund Bleischwitz and Nikolas Bader

BEEP briefing $n^{\circ} 18$ (September 2007)

How Social is European Integration?, by Jacques Pelkmans.

BEEP briefing $n^{\circ} 17$ (September 2007)

The Sustainability Impact of the EU Emissions Trading System on the European Industry, by Raimund Bleischwitz, Katrin Fuhrmann and Elias Huchler.

BEEP briefing $n^{\circ} 16$ (March 2007)

Services in European Policies, by Luis Rubalcaba.

BEEP briefing $n^{\circ} 15$ (July 2006)

European Industrial Policy, by Jacques Pelkmans.

BEEP briefing $n^{\circ} 14$ (March 2006)

Has the European ICT Sector a Chance to be Competitive? by Godefroy Dang Nguyen \& Christan Genthon.

BEEP briefing $n^{\circ} 13$ (February 2006)

Testing for Subsidiarity, by Jacques Pelkmans

BEEP briefing $n^{\circ} 12$ (November 2005)

La gestion de la transition vers la monnaie unique et l'établissement de la crédibilité de l'euro, by Jean-Claude Trichet.

BEEP briefing $n^{\circ} 11$ (September 2005)

Does the European Union Create the Foundations of an Information Society for all?, by Godefroy Dang Nguyen \& Marie Jollès.

BEEP briefing $n^{\circ} 10$ (January 2005)

A 'Triple-I' Strategy for the Future of Europe, by Raimund Bleischwitz.

BEEP briefing $n^{\circ} 9$ (December 2004)

The Turkish Banking Sector, Challenges and Outlook in Transition to EU Membership, by Alfred Steinherr, Ali Tukel \& Murat Ucer.

BEEP briefing $n^{\circ} 8$ (October 2004)

The Economics of EU Railway Reform, by Jacques Pelkmans \& Loris di Pietrantonio. 
BEEP briefing $n^{\circ} 7$ (June 2004)

Sustainable Development and Collective Learning: Theory and a European Case Study, by Raimund Bleischwitz, Michael Latsch \& Kristian Snorre Andersen

BEEP briefing $n^{\circ} 6$ (January 2004)

Can Europe Deliver Growth? The Sapir Report and Beyond, by Jacques Pelkmans \& Jean-Pierre Casey.

BEEP briefing $n^{\circ} 5$ (April 2003)

Efficient Taxation of Multi-National Enterprises in the European Union, by Stefano Micossi, Paola Parascandola \& Barbara Triberti.

BEEP briefing $n^{\circ} 4$ (April 2003)

EU Enlargement: External Economic Implications, by Jacques Pelkmans \& Jean-Pierre Casey.

BEEP briefing $n^{\circ} 3$ (March 2003)

Mutual Recognition, Unemployment and the Welfare State, by Fiorella Kostoris Padoa Schioppa.

BEEP briefing $n^{\circ} 2$ (December 2002)

Mutual Recognition in Goods and Services: an Economic Perspective, by Jacques Pelkmans.

BEEP briefing $n^{\circ} 1$ (October 2002)

Economic Implications of Enlargement, by Jacques Pelkmans. 